Jasmina D. Moskovljević Popović $\square$ УДК

Filološki fakultet, Beograd ${ }^{\square *} \quad$ 81'34

ДОИ

https://doi.org/10.18485/analiff.2016.28.1.20

\title{
O KORELATIVNIM KONSTRUKCIJAMA U JUŽNOSLOVENSKOJ LINGVISTICI (I)
}

Osnovni cilj ovog rada je da pruži delimičan pregled istraživanja korelacije, korelativnih veznika i korelativnih konstrukcija u južnoslovenskoj lingvistici s kraja 19. i tokom 20. veka. Iako se ovi termini javljaju vrlo rano - prisutni su već u gramatikama iz 19. veka, oni ni do danas nisu jednoznačno i precizno definisani, kao što nema ni saglasnosti oko funkcija koje klauze sa korelativom vrše u okviru složene rečenice.

Ključne reči: složena rečenica, zavisna klauza, korelativne konstrukcije, korelativi, južnoslovenska lingvistika

\section{Uvod}

U lingvistici se termin korelativ upotrebljava u više različitih i međusobno nezavisnih značenja. U fonologiji Praške strukturalističke škole njime se označava „sistemski odnos između dve serije glasova“ (Kristal 1988:133), dok ga Martine, u skladu sa svojim funkcionalističkim pristupom, upotrebljava u nešto izmenjenom značenju određujući fonološki sistem kao ,paradigme integrisanih strukturnih jedinica koje su bazirane na funkcionalnim korelacijama distinktivnih obeležja (Martinet 1939a,b). U sintaksi tradicija upotrebe izraza korelativ seže sve do antičkih vremena - korelativni veznici pominju se još u Aristotelovoj Retorici. Na početku pete glave trećeg dela kao prvi od pet uslova od kojih zavisi pravilnost govora navodi se pravilna upotreba veznika, odnosno da korelativni veznici moraju biti uzajamno usklađeni i ,razmešteni kao što po svojoj prirodi treba da budu razmešteni“, kao i da ,ne valja da između dva veznika postoji veliki razmak“, kako bi se slušalac još sećao prvog u trenutku kad čuje drugi. ${ }^{3}$

\footnotetext{
* Katedra za opštu lingvistiku, Filološki fakultet, Studentski trg 3, 11000 Beograd, jasmina.moskovljevic@,fil.bg.ac.rs.

** Rad autora ovog članka podržan je u okviru projekta ,,Standardni srpski jezik: sintaksička, semantička i pragmatička istraživanja“ (178004), koji finansira Ministarstvo prosvete i nauke Republike Srbije.

3 Navedeno prema Householder (1995: 94); up. i Aristotel (1987: 218).
} 
Enciklopedije, rečnici i gramatike sa južnoslovenskih prostora iz druge polovine 19., kao i one iz prošlog veka, gotovo uvek sadrže i odrednicu o korelativima i korelativnoj vezi među rečenicama. Korelativ se najčešće definiše kao „onaj jezični element u rečenici, koji nužno upućuje na drugi““, ${ }^{1}$ odn. navodi se da je korelacija ,suprotstavljanje ili zbližavanje jedinica jezika po određenim svojstvima“. Slično ovome (i podjednako neodređeno), u Matičnom rečniku i Rečniku SANU stoji da je korelacija „međusobni odnos, uzajamna zavisnost, povezanost u harmoničnu celinu“, korelat je „ono što stoji u uzajamnom odnosu sa nečim drugim“, a korelativ ,(gram.) je reč ili izraz koji stoji u uzajamnom odnosu sa drugom reči“‘. ${ }^{2}$

Specijalizovani rečnici lingvističkih termina nešto su određeniji. U Enciklopedijskom leksikonu srpskohrvatskog jezika navodi se da je korelativ „ . . . jezički element, reč ili grupa reči koja stoji u suodnosu s drugom rečju ili grupom reči i nužno upućuje na njih"“3, dok Enciklopedijski rječnik lingvističkih naziva sadrži više različitih odrednica koje se odnose na korelaciju i korelative (Simeon 1969, knj. II: 707-709). U ovom rečniku korelacija se objašnjava kao ,uzajamna uvjetovanost, semiološka zavisnost dviju ili više jezičnih jedinica; ... koja ,nastaje kada se kao jedan priložni izraz i sa jednim značenjem upotrebljavaju po dva priloga u korelaciji“. U nastavku teksta sledi: „,u korelaciju (riječi) pripada . . . uzajamna zavisnost, . . . kao i ponovno prihvaćanje i ponovno spominjanje nekog dijela rečenice u drugoj rečenici; . . . ti slučajevi pripadaju ujedno i u korelaciju rečenica, budući da tu korelativne riječi služe ujedno kao korelativi rečenica, tvoreći korelativnu rečeničnu svezu“. Korelat je ,riječ koja stoji unutar sintaksnog polja na mjestu jednog člana rečenice koji u stražnjem polju zastupa zavisna rečenica; time korelat najavljuje tu zavisnu rečenicu“. I na kraju, tu je i definicija suodnosnosti u kojoj se ova određuje kao „,vrsta sintaksne sveze koja se ustanovljuje između odnosnih zamjenica i njihovih antecedenata" (ibid.: 554).

\section{Korelativni veznici i konstrukcije u starijim južnoslovenskim gramatikama i jezičkim studijama}

Korelativni veznici i konstrukcije pominju se i u najstarijim gramatikama sa južnoslovenskih prostora. U Ilirskoj slovnici V. Babukića korela-

$1 \quad$ Enciklopedija leksikografskog zavoda 4, 1959: 362.

2 Rečnik srpskohrvatskog književnog i narodnog jezika 10: 246; Rečnik srpskohrvatskoga književnog jezika 2: 851.

3 Grupa autora (1972: 196). 
tivnost je bitna odrednica rečenične zavisnosti. Govoreći o zavisnom odnosu među rečenicama, odnosno o „stavačnoj sglobi“, on kaže: „Pobočni stavak mora se vavek pretezati na glavni stavak. Pretezanje (odnošenje) pobočnoga na glavni stavak sglobe stavačne naznačuje se podrednimi veznici. Svaki podredni veznik je uprav govoreći dvoudan i sastoji se iz pokaznoga i odnosnoga veznika. Pokazni veznik stoji u glavnom stavku, a odnosni u pobočnom“" (Babukić 1854: 410). Zanimljivo je da se i u nekim savremenim hrvatskim gramatikama polazi od vrlo sličnog stava da je svaki veznik zavisnih rečenica zapravo složen i sastoji se od dva segmenta (v. u drugom delu rada).

I A. Weber Tkalčević u Skladnji ilirskoga jezika (1862) uočava korelaciju kao moguću jezičku pojavu u nekim tipovima zavisnih rečenica. Dok govori o upotrebi vremenskog veznika kad, navodi da se „u sledećoj izreci, koja se na onu odnosi, metje (se) često veznik onda“ (ibid.: 126). Pišući nešto kasnije o ,prispodobnim“ (poredbenim) rečenicama, on beleži: „Pred drugu reč ili izreku, metju se za prispodobnimi veznici, osim za nego, nego što, veznici: tako, ovako, onako" (ibid.: 132). Pri tome se složene rečenice sa zavisnom klauzom adverbijalnog značenja prema kojima se u strukturi upravne klauze nalazi korelativ ni na koji način ne izdvajaju od rečenica bez korelativa u upravnoj klauzi.

U studiji o relativnim rečenicama A. Musić razlikuje dve različite kategorije ovih rečenica: „U jednima se relativ proteže na supstantiv, a zameniti se može anaforičkim ili demonstrativnim pronomenom (adjektivom ili adverbom) ..." (Musić 1899: 70). Primer koji navodi za ovaj tip rečenica je No ne fala mojoj staroj majci, koja svoje iskobi dijete i objašnjava da se ,koja proteže na supstantiv „majka“, a zameniti se može anaforičkim pronomenom ona: No ne fala mojoj staroj majci, ona svoje iskobi dijete“" (ibid.). U drugi tip svrstava rečenice u kojima se „relativ proteže na korelativni demonstrativni ili anaforički pronomen (adjektiv ili adverb), koji se veoma često i izostavlja“ (ibid.: 72). Među primerima koje navodi, mahom iz Vukovog i jezika narodnih umotvorina, nalaze se: Kakvo sjeme posiješ, onako ćeš $i$ žito vrći; Đe ko nikne, tu se i obikne, Ko zna bolje, široko mu polje i sl. Ovakav odabir primera nedvosmisleno ilustruje da je Musić sve rečnice sa korelativima, kako one atributskog i nominalnog, tako i one adverbijalnog značenja svrstavao u istu kategoriju - kategoriju relativnih rečenica. Dalje u radu, objašnjavajući prirodu rečenica sa korelativima on uspostavlja vezu prvo između korelativnih i konsekutivnih, a potom i između korelativnih i koncesivnih rečenica, da bi na kraju zaključio da „u relativnim rečenicama II kategorije relativ uvek ima značenje kao gener- 
alni indefinitum; relativ se u njima može zameniti makar kojim individualnim pojmom iste kategorije, ali uz hipotetičku konjunkciju, t. j. tko= ako $x$, ako y, ako z ..." (ibid.: 84), odnosno, da su ,relativne rečenice druge kategorije zapravo hipotetičke rečenice“" (ibid.: 92). ${ }^{4}$ Musićev pokušaj da objasni i argumentuje svoj stav o prirodi korelativnih konstrukcija i njihovom odnosu prema drugim tipovima zavisnosloženih rečenica jedini je pokušaj te vrste u južnoslovenskoj lingvistici 19. i prve polovine 20. veka.

T. Maretić je u Gramatici hrvatskoga ili srpskoga književnog jezika, u poglavlju posvećenom veznicima, uz svaki veznik, veznički spoj i prilog u vezničkoj službi naveo ne samo tip zavisne rečenice u kojoj se on javlja, već i potencijalne korelativne parnjake datog veznika (1899/1963: 533552). Tako, na primer, kaže: „Za korelaciju takvome dok (dokle) može služiti $a$ to, tada ... Za korelaciju vremenskome kada (kad) mogu služiti riječi: a, a ono, a to, ali, dok, kadli, no, onda, pa, tada, te, tu (i samo tu znači katkad) ... U korelaciji s veznikom kako mogu biti riječi: $a$, ta (veoma rijetko), tako ... U korelaciji prema pošto mogu biti riječi $a$, no, onda ... U korelaciji (prema tek) može biti a, ali, $i$... Veoma su obični u korelaciji adverbi: onako, tako,: kako ... Prema budući da mogu biti u korelaciji riječi tako, to, zato ... Obično prema posljedičnom da stoji u glavnoj rečenici korelativno tako... “( ibid.). A sam pojam „korelacija“ definisao je na sledeći način: „Rečenice se često vežu dvojako veznicima (ili riječma koje služe kao veznici), tj. prema vezniku (ili prilogu) zavisne rečenice stoji i u glavnoj kakva riječca koja mu odgovara, tako npr. imamo u zavisnoj i u glavnoj rečenici često: kada - tada, kako - tako, da-onda, ako - to itd. To se zove k o r e 1 a c i j a. Ali često se grade rečenice bez korelacije, tj. često u glavnoj rečenici nema nikakve riječi koja bi odgovarala vezniku (ili prilogu) zavisne rečenice“" (ibid.: 533).

Iz navedene definicije jasno je da Maretić, kao i Weber (a suprotno od Musića), ne smatra da prisustvo (ili odsustvo) korelativa u strukturi upravne klauze na bilo koji način utiče na funkcionalno-sintaksički status zavisne klauze - zavisna adverbijalna klauza ostaje zavisna adverbijalna klauza bez obzira na to da li je u strukturu nadređene klauze uključen korelativni adverb (ili neki njegov funkcionalni ekvivalent). Uz to, Maretić je među korelative uključio i prave veznike $(a, a l i, i, p a \ldots)$.

$4 \quad$ Zanimljivo je da je sto deset godina kasnije do istog zaključka došao i Arsenijević (2009:153): "Building on this proposal, correlative clauses were analyzed as conditionals with topical extreme non-specific arguments." 
U „Srpskoj gramatici“ S. Novakovića (1902) termin korelativ uopšte se ne pojavljuje, ali on u okviru razmatranja pridevskih, načinskih, vremenskih, mesnih i uzročno-posledičnih rečenica navodi i primere složenih rečenica $u$ kojima se unutar upravne klauze pojavljuje i korelativ. Kako ih ni na koji način ne izdvaja, jasno je da su i za njega korelativne strukture samo jedan strukturni podtip odgovarajućeg funkcionalno determinisanog tipa zavisne klauze.

U one koji korelaciju ne izdvajaju kao poseban vid pripajanja zavisne rečenice upravnoj spada i Lalević (1951). On sve zavisne rečenice razvrstava u deset kategorija: temporalne, finalne, modalne i komparativne, deklarativne, kauzalne, konsekutivne, koncesivne, relativne, kondicionalne, a u poslednju kategoriju rečenica uvrstio je indirektna pitanja. Govoreći potom podrobnije o svakoj od pobrojanih kategorija, naveo je i one reči i skupove reči koji se mogu pojaviti kao njihovi korelativi. Među njih je, kao i Maretić, uključio i prave veznike. Ni u njegovoj klasifikaciji prisustvo, odn. odsustvo korelativa u upravnoj klauzi ne igra nikakvu ulogu kad je reč o određivanju kategorije kojoj zavisna rečenica pripada (Lalević, 1951).

Klasifikaciju koja je donekle slična Lalevićevoj, a i većini prethodno navedenih (bar kad je o statusu korelativnih struktura reč), predložili su i Brabec, Hraste i Živković (1965). Njihova podela je, međutim, znatno drugačija kad je reč o osnovnim kriterijumima za klasifikaciju zavisnih rečenica. Dok Lalević parametre razvrstavanja odabire u sferi rečeničnog značenja, odn. prema sadržaju koji zavisne klauze iskazuju i preko koga određuju i preciziraju značenje upravne rečenice, dotle Brabec, Hraste i Živković za polaznu tačku svoje klasifikacije uzimaju sintaksičke funkcije koje zavisne klauze vrše u okviru složene rečenice. Oni skup zavisnih rečenica u prvom koraku razvrstavaju na podskupove subjekatskih, predikatskih, atributskih, objekatskih i adverbijalnih rečenica, da bi potom u okviru adverbijalnih rečenica izdvojili sledeće podtipove zavisnih klauza: a) načinske, b) poredbene, c) mesne, d) vremenske, e) uzročne, f) posledične, g) namerne, h) pogodbene i i) dopusne rečenice. Kad je o korelativnim strukturama reč, Brabec, Hraste i Živković u istu grupu - odnosnih subjekatskih rečenica - svrstavaju sledeće primere, uprkos očitim razlikama u njihovoj strukturi: Tko nije pelin gutao, ne zna šta je sladost; Koji ne može čekati, doći će sutra; Tko se ne namuči, on se ne nauči; Tko se dima ne nadimi, taj se ognja ne nagrija. Za poslednja dva primera, odnosno za rečenice sa korelativom u upravnoj klauzi, oni kažu: 
„U takvim rečenicama vidimo dva subjekta: rečenicu i pokaznu zamenicu. U prvome primjeru je subjekt glavne rečenice on i Tko se ne namuči. Pravi subjekt je rečenica, jer ona nam kazuje tko se ne nauči. Zamjenica sama ne kazuje ništa određeno, nego samo ističe pravi subjekt i daje rečenici više živosti" (ibid.: 204). Korelativne konstrukcije tako se izdvajaju kao konstrukcije sa dva subjekta, od kojih je jedan ,,pravi“, a drugi formalni, ali sa određenom stilskom vrednošću (,daje rečenici više živosti“").

U nastavku teksta Brabec, Hraste i Živković u atributske relativne rečenice svrstavaju, između ostalih, i ,rečenice koje se vežu odnosnim prilozima gdje, kamo kuda, otkuda, kad itd: Upisao se u onu školu gdje će se najbolje osposobiti za život. Zar niste čuli za onaj Ilindan kada je počeo ustanak?, ali nešto kasnije, u poglavljima o različitim tipovima adverbijalnih rečenica, ponovo navode rečenice uvedene istim prilozima, ovaj put kao ilustraciju za različite tipove adverbijalnih klauza: Gdje je nekad slab potočić žuborio, tu se danas Tuškanac prostire. Otkud sam se nadao suncu, odonud me led bije. Kad ujutro ustanem, a to vuci došli te zaklali mog pčelca (ibid.: 205-208 ).

Kako ovi autori ne upotrebljavaju termin korelativ (mada su korelativi pojavljuju u primerima kojima ilustruju pojedine tipove rečenica), a i ne navode kriterijume na osnovu kojih vrše razlikovanje relativnih atributskih i adverbijalnih klauza uvedenih prilozima, ostaje nejasno kako uspostavljaju distinkciju među ovim tipovima klauza, kao i koja bi bila uloga i status korelativnih konstrukcija u njihovom gramatičkom sistemu.

Kad je o starijim gramatikama reč, korelaciji i korelativnim konstrukcijama najviše pažnje posvetio je Stevanović (1979). On sve zavisne rečenice prvo deli na odredbene i dopunske: „I nesumnjivo će najtačnija definicija zavisnih rečenica biti ako se o njima kaže da su to uvek odredbe ili dopune rečenica ili pojedinih delova rečenica od kojih zavise. Zato je zavisne rečenice i potrebno prvo podeliti na dve kategorije: na kategoriju dopunskih i kategoriju odredbenih rečenica ..." (ibid.: 819). U kategoriju dopunskih svrstavaju se izrične (u širem smislu) i namerne rečenice, a u kategoriju odredbenih odnosne, vremenske, mesne, poredbene i načinske, uzročne, posledične, pogodbene i dopusne rečenice.

Prisustvo (odnosno mogućnost prisustva) korelativa u strukturi nadređene rečenice za Stevanovića je jedan od testova za razlikovanje atributskih i apozitivnih relativnih rečenica: „prema odnosnim atributskim rečenicama, kao njihovi korelativi uz upravne reči, obično dolaze ili mogu doći (mada ne uvek) pokazne zamenice: onaj (ona, ono), taj (ta, to), takav 
(takva, takvo) (ibid. : 852). Kada govori o odnosnim rečenicama sa što, on ističe: „Kada se što na početku odnosnih rečenica odnosi na neku zamenicu, ne neodređenu imeničku zamenicu nešto, recimo, ali i na ovo, to, ono, ili sve - samo naravno ne nikada na te reči upotrebljene u funkciji pridevske zamenice - relativna reč toga korelativa je isključivo zamenica-veznik što...". Potom navodi strukturno različite primere koji pokazuju da je za njega kategorija korelativnih konstrukcija vrlo široka: Što se ne htje u lance vezati, to se zbježa u ove planine. Zaboravlja na ono što je bilo i sve manje misli na ono što će biti. Jeste u meni nešto čvrsto što se lomi. Obrati pažnju na nešto što nije vidjela. Ovo što se noćas desilo, to je već skovan plan (ibid.: 860). ${ }^{5}$

Ono što je međutim posebno značajno u Stevanovićevom pristupu korelativima i korelativnim konstrukcijama jeste da je on prvi sintaksičar koji ukazuje na promenu sintaksičke funkcije zavisne klauze u zavisnosti od prisustva/odsustva korelativa u nadređenoj klauzi: , još ćemo nešto reći o posebnim funkcijama rečenica s relativnim veznikom što, prema kome uvek u glavnoj (odn. upravnoj) rečenici kao korelative imamo neodređene i sl. zamenice srednjeg roda (nešto, ovo, to, ono i sve). Zajedno s tim korelativima one mogu biti u različnim jezičkim funkcijama. One ... mogu biti subjekti ... jedan deo predikata. Još ponajviše navedenih primera, kad bi bili oslobođeni korelativne zamenice, imali bi funkciju objekta ..."(ibid.: 862).

Držeći se istog, formalnog kriterijuma, on kao relativne klasifikuje i sve rečenice adverbijalnog značenja prema kojima se u strukturi upravne rečenice nalazi korelativ. Među njih ubraja odnosne rečenice „za određivanje mesta, odn. prostora, koje se za glavne vezuju prilozima kud, otkud i kamo, prema kojima, kao korelativ, u glavnoj rečenici stoji opet kakva reč ili sintagma mesnog značenja. ... U odnosne isto tako idu i rečenice za iskazivanje načinske odredbe već izrečene nekom rečju ili sintagmom glavne rečenice, koja u ovoj stoji kao korelativ odnosnom prilogu ili priloškom izrazu kako ili kao što, kojima se takve odnosne rečenice vezuju za glavne. ... Nešto su češće odnosne rečenice sličnoga tipa za bliže određivanje neke vremenske odredbe već izrečene, bilo jednom rečju bilo sintagmom koja kao korelativ stoji u upravnoj rečenici. ... I ovde, kao i u slučaju s odnosnim rečenicama u funkciji određivanja mesta i načina, $u$ glavnoj rečenici, kao korelativ odnosnoj, stoji reč ili sintagma na koju se ova rečenica odnosi.“ (ibid.: 867-868).

5 Među primerima se našla čak i jedna rečenica u kojoj uopšte nema korelativa: $T e$ tako on posta što ni u snu nije mogao sanjati. 
Stevanović insistira na klasifikaciji ovakvih rečenica kao odnosnih i u onim slučajevima kad je, unutar istog rečeničnog tipa, pojava rečenica sa korelativom mnogo češća nego pojava rečenica bez korelativa: , ...zavisne mesne rečenice češće posredno, preko nekog priloga ili priloškog izraza, određuju mesto vršenja radnje (stanja ili zbivanja) upravne rečenice nego što tu službu vrše neposredno, kao prave zavisne mesne rečenice. ... Mi ovde, kao i u još ponekom slučaju, navodimo primere zavisnih rečenica i za posredno i neposredno određivanje mesta zajedno, iako i ovde samo druge idu u prave mesne rečenice, koje bez ikakvog korelativa određuju mesto onoga što se kazuje predikatom upravne rečenice, i iako prve, kao i u drugim takvim slučajevima, njihov korelativ u istoj funkciji čini odnosnim rečenicama“" (ibid.: 882-885).

Kao relativne Stevanović određuje i uzročne rečenice s vezničkim skupovima zbog toga što, usled toga što, zahvaljujući tome što i zato što tvrdeći da raščanjavanje ovih skupova pokazuje da je ,samo poslednja reč, što - pravi veznik ...dok su delovi ispred što u stvari korelativni delovi upravnih rečenica“" (ibid.: 890). Jedino pri razmatranju strukture pogodbenih i dopusnih rečenica Stevanović ne pominje mogućnost pojave korelativa mada se u brojnim primerima koje navodi mogu izdvojiti i oni sa korelativima, kao što se i u propratnom tekstu kojim objašnjava date primere mogu pronaći njegove sopstvene rečenice u kojima je kondicionalna ili dopusna rečenica pripojena upravnoj uz pomoć korelacije. Da je i kod ovih rečenica dosledno sprovedeno izdvajanje rečenica sa korelativima i njihovo priključenje relativnim rečenicama, klasifikaciona dihotomija bila bi potpuna - unutar sistema relativnih rečenica postojale bi mesne, vremenske, načinske... kondicionalne, a naspram njih bi postojao izdvojen sistem ,pravih“ mesnih, vremenskih, načinskih ... kondicionalnih rečenica. Mada je predloženim rešenjima Stevanović ovakvu podelu implicitno nagovestio, on je nije i sproveo, kao što nigde nije ponudio ni argumente i/ili objašnjenje zašto je klasifikaciju korelativnih konstrukcija izvršio baš na način kako je to učinio.

\section{Završne napomene}

Pregled i analiza jezičkih studija i gramatika predstavljenih u ovom radu svedoče o tome u kojoj meri su korelacija, korelativi i korelativne konstrukcije bili istovremeno i prisutan i nedovoljno ispitan i razjašnjen 
problem u južnoslovenskoj lingvistici 19. i većeg dela 20. veka. Između ostalog, ni same granice problema nisu jasno omeđene, pa različiti autori na različit način određuju koje se konstrukcije ubrajaju u korelativne, a koje ne. Podele su još veće i odgovori još nejasniji kada je reč o funkcionalnom statusu zavisne klauze - da li i na koji način prisustvo korelativa u upravnoj klauzi menja funkcionalni status zavisne klauze? Da li je korelativ u korelaciji samo sa relativom ili sa čitavom zavisnom klauzom? Da li je korelativno povezivanje poseban, izdvojen tip rečeničnog povezivanja koji predstavlja prelazni oblik između naporednog i zavisnog vezivanja, ili ne?

Nabrojana, i još čitav niz drugih pitanja na koja nisu pruženi precizni, argumentovani i teorijski utemeljeni odgovori upućuju na zaključak da je, kad je o korelaciji i korelativnim konstrukcijama reč, još mnogo toga neispitano i nepoznato. A da je reč o važnom jezičkom fenomenu, vidi se i po tome što se razlika u strukturi između zavisnosložene rečenice sa korelativom i one u čijoj stukturi on nije prisutan, ne iscrpljuje samo u postojanju jednog vezničkog elementa više u strukturi rečenice sa korelativom, već se proširuje i na samu prirodu odnosa koji vladaju unutar složene rečenice - više nije samo zavisna klauza podređena upravnoj, već i upravna klauza postaje značenjski nepotpuna bez zavisne. Tako se umesto odnosa jednostrane determinisanosti razvija odnos međuzavisnosti, što nužno menja ne samo prirodu međusobnog odnosa klauza unutar složene rečenice, već bi moralo da vodi i ka drugačijem teorijskom određenju i objašnjenju ovog odnosa.

\section{Literatura}

Aristotel (1987): Retorika 1/2/3. Pevod: Marko Višić. Beograd: nezavisno izdanje.

Arsenijević, B. (2009): „\{Relative \{conditional \{correlative clauses\}\}\}“" Iz : Liptak, A. (ed.), Correlatives Cross-Linguistically. Amsterdam: John Benjamins, 131-156.

Babukić,V. (1854): Ilirska slovnica. Zagreb: Bérzotiskom nar. tiskarnice dra. L. Gaja.

Brabec, I. - Hraste, M. - Živković, S. (1968 $)$ : Gramatika hrvatskosrpskoga jezika. Zagreb: Školska knjiga.

Grupa autora (1972): Enciklopedijski leksikon "Mozaik znanja - srpskohrvatski jezik". Beograd: Interpres.

Householder, F. W. (1995): „Aristotle and the Stoics on Language“. Iz: Ko- 
erner, E. F. K. i Asher, R. E., Concise History of the Language Sciences from the Sumerians to the Cognitivists. Oxford: Elsevier, 93-99. Lalević, M. S. (1951): Sintaksa srpskog jezika. Beograd: VPŠ.

Maretić,T. (1899/1963): Gramatika hrvatskoga ili srpskoga književnog jezika. Zagreb: Matica hrvatska.

Martinet A. (1939a): „La Phonologie synchronique et diachronique“, Revue des Cours et Conférences, XL, 332-40.

Martinet A. (1939b): ,Rôle de la corrélation dans la phonologie diachronique", Travaux du Cercle Linguistique de Prague, VIII, 273-88.

Musić, A. (1899): „Relativne rečenice u hrvatskom jeziku“, Rad Jugoslavenske akademije znanosti i umjetnosti, 138, 70-117.

Musić, August (1900): „Rečenice s konjunkcijom da u hrvatskom jeziku“, Rad Jugoslavenske akademije znanosti i umjetnosti, 142, 1-125.

Novaković, S. (1902): Srpska gramatika. Beograd: Državna štamparija.

Rečnik srpskohrvatskog književnogjezika, knj. 2. Novi Sad : Matica srpska.

Rečnik srpskohrvatskog književnog i narodnog jezika, knj. 10. Beograd: SANU i Institut za srpski jezik.

Simeon, R. (1969): Enciklopedijski rječnik lingvističkih naziva I, II. Zagreb: Matica hrvatska.

Stevanović, M. (19793): Savremeni srpskohrvatski jezik II. Beograd: Naučna knjiga.

Weber Tkalčević, A. (1859/1862): Skladnja ilirskoga jezika, za niže gimnazije. Beč.

Jasmina Moskovljević Popović

\section{Summary}

\section{ON CORRELATIVE CONSTRUCTIONS \\ IN SOUTH-SLAVIC LINGUISTICS (I)}

The major objective of this paper is to present a partial survey of the research on correlation, correlative subordinators and correlative constructions in South-Slavic linguistics at the end of the $19^{\text {th }}$ and during the $20^{\text {th }}$ century. Even though these concepts are already present in the 19th-century grammar books, they have not been precisely and uniquely defined to this day. The same applies to the syntactic functions which the clauses with correlatives perform in a complex sentence - an agreement regarding their functional status has not been reached among the grammarians yet. 